\title{
Cytotoxicity of Fucoidan from Three Tropical Brown Algae Against Breast and Colon Cancer Cell Lines
}

\author{
Alim Isnansetyo ${ }^{1}$, Fadilah Nor Laili Lutfia ${ }^{2}$, Muhammad Nursid ${ }^{3}$, Trijoko ${ }^{4}$, Ratna Asmah Susidarti ${ }^{5}$
}

\section{Alim Isnansetyo', Fadilah Nor Laili Lutfia ${ }^{2}$, Muham- mad Nursid ${ }^{3}$, Trijoko ${ }^{4}$, Ratna Asmah Susidarti ${ }^{5}$}

\author{
'Department of Fisheries, Faculty of \\ Agriculture, GadjahMada University, \\ J. Flora, Bulaksumur, Yogyakarta, \\ INDONESIA. \\ ${ }^{2}$ Study Program of Biotechnology, Post \\ Graduate School, GadjahMada University, \\ INDONESIA. \\ ${ }^{3}$ Research and Development Center for \\ Marine and Fisheries Product Processing \\ and Biotechnology, Ministry of Fisheries \\ and Marine Affair, INDONESIA. \\ ${ }^{4}$ Faculty of Biology, GadjahMada \\ University, Sekip Utara, Yogyakarta, \\ INDONESIA. \\ ${ }^{5}$ Faculty of Pharmacy, GadjahMada \\ University, Sekip Utara, Yogyakarta, \\ INDONESIA.
}

\section{Correspondence}

Alim Isnansetyo, Departement of Fisheries, Faculty of Agriculture, Gadjah Mada University, JI Flora, Bulaksumur, YOGYAKARTA 55281,

Phone: +62-274-551218,

E-mail: isnansetyo@yahoo.com; isnansetyo@ugm.ac.id

History

- Submission Date: 18-07-2016;

- Review completed: 22-08-2016;

- Accepted Date: 10-09-2016.

DOI : 10.5530/pj.2017.1.3

Article Available online

http://www.phcogj.com/v9/i1

Copyright

(C) 2016 Phcog.Net. This is an openaccess article distributed under the terms of the Creative Commons Attribution 4.0 International license.

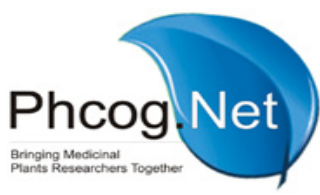

\begin{abstract}
Introduction: Fucoidan is a sulfated polysaccharide that has a wide range of bioactivities including anti-cancer. This polysaccharide commonly is extracted from marine brown seaweed. There is lack of information on the fucoidan extracted from tropical brown algae and its anti-cancer activity. Objectives: The objectives of this study were to purify fucoidan from Sargassum sp., Turbinaria sp. and Padina sp., and to evaluate their cytotoxicity against breast cancer (MCF-7) and colon cancer cells (WiDr). Materials and Methods: Fucoidan extraction was conducted by using acid extraction method. Purified fucoidans were obtained by DEAE cellulose column chromatography and confirmed by HPLC and FT-IR spectrometry. The cytotoxicity was evaluated by using the MTT (3-[4,5-dimethylthiazol-2-yl] -2,5- diphenyltetrazolium bromide) assay. Results: Fucoidan from Sargassum sp. and Turbinaria sp. showed low cytotoxicity with $\mathrm{IC}_{50}$ ranging between 461-663 $\mu \mathrm{g} / \mathrm{mL}$. Higher cytotoxicity against MCF-7 and WiDr was showed by fucoidan from Padina sp. with $\mathrm{IC}_{50}$ of 144 and $118 \mu \mathrm{g} / \mathrm{mL}$, respectively. While its $\mathrm{IC}_{50}$ against Vero cells was $501 \mu \mathrm{g} / \mathrm{mL}$. Standard fucoidan from Fucus vesiculosus exhibited $\mathrm{IC}_{50}$ of 60,63 and $211 \mu \mathrm{g} / \mathrm{mL}$ against MCF-7, WiDr and Vero Cells, respectively. Although the $\mathrm{IC}_{50}$ was higher than that of standard fucoidan, Padina sp. fucoidan showed cytotoxicity comparable with standard fucoidan at concentrations below $100 \mu \mathrm{g} / \mathrm{mL}$. Conclusion: These results indicated that Padina sp.fucoidan showed potential selective cytotoxicity, and promising for the development of an anti-cancer compound.
\end{abstract}

Key words: Fucoidan, Breast cancer, Colon cancer, Phaeophyta, Cytotoxicity.

\section{INTRODUCTION}

Fucoidan is a polysaccharide of brown seaweed and marine invertebrates (such as sea urchin and sea cucumber) with a main component of L-fucose and sulfate ester group. ${ }^{1}$ Chemical structure of fucoidan from brown seaweed is very complex and varies among seaweeds species. ${ }^{2}$ The main difference is in the backbone structure of fucoidan. ${ }^{3,4}$ Monosaccharides component of fucoidan affect their physiological and biological activities. ${ }^{5}$ Fucoidan has a wide range of bioactivity among others as immunostimulan,,$^{6-9}$ and antitumor/anticancer. ${ }^{4,10,11}$

Cancer is a disease that attacks the modern society globally, and as a major disease today and in the future. WHO have reported that there are 14 million new cases and 8.2 million cancer related death in 2012, and annual cancer cases will rise to 22 million within the next two decades. ${ }^{12}$ Two cancers that cause the major deaths in men are lung cancer and colorectal cancer, whereas in women are breast cancer and lung cancer. ${ }^{13}$ Girish et $\mathrm{l}^{14}$ have found the potential activity of Pavonia odorata Willd extract against human breast and lung cancers. Breast cancer is also effectively inhibited by $\beta$-mangostin isolated from Cratoxylum arborescens either in vitro or in vivo. ${ }^{15}$ How ever, research on tropical brown seaweeds as sources of fucoidan for anti-cancer agent is still limited.

Cumashi $e t$ a $l^{5}$ have found the potent anti-angiogenesis activity of fucoidan from Laminaria saccharina, L. digitata, Fucus evanescens, F. serratus, F. distichus, F. spiralis, F. vesiculosus, Ascophyllum nodosum and Cladosiphon okamuranus. Fucoidans from L. saccharina, L. digitata, F. serratus, F. distichus, and F. vesiculosus strongly blocks MDAMB-231 breast carcinoma cell adhesion to platelets. A commercial fucoidan from $F$. vesiculosus also active against HCT-15 colon carcinoma cells through apoptosis- inducing activity. ${ }^{16}$ Senthilkumar et al ${ }^{17}$ have reviewed the fucoidan from $F$. vesiculosus, C. novae-caledoniae, C. okamuranus, S. japonica, U. pinnatifida with cytotoxicity against cancer cells. Fucoidan from Sargassum sp. and $F$. vesiculosus also reduces viability of lung carcinoma and melanoma cells. ${ }^{18}$ Fucoidan from Eclonia cava, Sargassum hornery, and Costaria costata from South Korea inhibits colony formation in human melanoma and colon cancer cells. ${ }^{19}$ Murphy et $a l^{20}$ have reviewed

Cite this article : Isnansetyo A, Laili Lutfia FN, Nursid M, Trijoko, Susidarti RA. Cytotoxicity of Fucoidan from Three Tropical Brown Algae Against Breast and Colon Cancer Cell Lines. Pharmacog J. 2017;9(1):14-20. 
anticancer substance including fucoidan from brown seaweeds. Marudhupandi et $a^{21}$ reported the cytotoxicity of fucoidan from a tropical brown seaweed, Turbinaria sp. collected from Tamilnadu India against the human lung cancer A549 cell line. In the present study we purified fucoidan from Sargassum sp., Turbinaria sp. and Padina sp., and evaluated its anticancer activity against colon and breast cancer cell lines. To the best of our knowledge, the anticancer activities of fucoidan from these three brown seaweeds species against these two cancer cell lines have not been reported before.

\section{MATERIALS AND METHODS}

\section{Sampling and Identification of Brown Seaweeds}

Sampling was carried out in the intertidal zone during low tide. Sargassum sp., Turbinaria sp. and Padina sp. were collected and then put in a cool box and transported to the laboratory. Identification was carried out based on Dhargalkar, ${ }^{22}$ Trono. ${ }^{23}$

\section{Extraction and Purification}

The seaweed samples were washed with fresh water, then air dried in the laboratory to obtain the dry biomass, and stored in plastic bags. Extraction was carried out by the method of Kim et al $^{13}$ Purification was carried out by DEAE cellulose column chromatography (Sigma-Aldrich, St. Louis, MO, USA) eluted with distilled water and gradient 0.5 to $3 \mathrm{M} \mathrm{NaCl}^{24}$ The total carbohydrate of the purified fucoidan in the fractions was determined by the phenol-sulfuric acid method according to Masuko et al ${ }^{25}$ using L-fucose as a reference. The fucoidan fractions were evaporated, dialysed (MW cut-off 12,300 Da) for 48 hours, then freeze-dried and stored at $4^{\circ} \mathrm{C}$ until use.

The purified fucoidan was analyzed by HPLC using Agilent Hi-Plex columns Ligand-Exchange (Agilent Hi-Plex H for Carbohydrate) $7.7 \times$ $100 \mathrm{~mm}$, with a refractive index detector (RID-10A, Shimadzu, Japan) with a flow rate of $0.7 \mathrm{~mL} / \mathrm{min}$ at $60^{\circ} \mathrm{C}$. HPLC using the autosampler (SIL-10ADVP, Shimadzu, Japan) with injection volume of $20 \mu \mathrm{L}$. Fucoidan sample concentration was $5 \mu \mathrm{g} / \mathrm{mL}$. The measurement of sulphate in the fucoidan was based on the barium sulphate $\left(\mathrm{BaSO}_{4}\right)$ determination using barium chloride $\left(\mathrm{BaCl}_{2}\right),{ }^{26}$ using $\mathrm{Na}_{2} \mathrm{SO}_{4}$ as a standard.

\section{FTIR spectra}

FTIR spectra were recorded by a FTIR spectrometer in $\mathrm{KBr}$ with a wave number range of $4000-450 \mathrm{~cm}^{-1}$. The ratio of fucoidan and $\mathrm{KBr}$ was approximately 1: 100 ( $2 \mathrm{mg}$ sample $+200 \mathrm{mg} \mathrm{KBr})$. The IR spectra of fucoidan from the seaweeds were compared with the IR spectrum of standard fucoidan (Sigma-Aldrich, St. Louis, MO, USA).

\section{Cytotoxicity Assay}

Cell lines used in this assay were a colon cancer cells (human collon adenocarcinoma cells) (WiDr), breast cancer cells (human breast adenocarcinoma cells) (MCF-7) and a normal cells, an African green monkey kidney cells (vero cells). Each of these cells were cultured in RPMI or M199 medium (Sigma-Aldrich, St. Louis, MO, USA) with the addition of $10 \%$ FBS (Sigma-Aldrich, St. Louis, MO, USA), antibiotics Panstrep (Gibco, Grand Island, NY, USA) and Fungison (Gibco). The cells were cultured at $37^{\circ} \mathrm{C}$ in a $\mathrm{CO}_{2}$ incubator until confluent. After incubation, the medium was replaced with a new medium, then the cells were harvested and re-cultured in 96-well microplate at a density of $10^{4} \mathrm{cells} / 100 \mu \mathrm{l} /$ well using a medium containing $2 \%$ FBS. Then fucoidan with a serial dilution was added to wells. As a negative control cells were treated with sterile dimethyl sulfoxide (DMSO), whereas the positive control was treated with a standard fucoidan from Fucus vesiculosus (Sigma-Aldrich, St. Louis, MO, USA). Cells were then incubated in the same conditions as above. Cells proliferation was observed by MTT assay (3- [4,5-dimethylthiazol- 2-yl] -2,5- diphenyltetrazolium bromide [Sigma-Aldrich, St. Louis, MO, USA $]) .{ }^{27}$ Growth was detected with a microplate reader at a wavelength of $570 \mathrm{~nm}$. The growth rate of cells exposed to fucoidan compared to the positive and negative controls, and then the cells mortality expressed in percent (\%) was calculated.

\section{RESULTS AND DISCUSSION}

Crude fucoidan extracts were purified by DEAE cellulose eluted with distilled water followed by 0.5 to $3 \mathrm{M}$ of $\mathrm{NaCl}$. Each fraction was measured for total sugar content with fucose as a standard (Figure 1). Fractionation of Sargassum sp. crude fucoidan showed the separation of the dominant fraction and two minor fractions. The main fraction was used for subsequent study.The fractionation of Turbinaria sp. crude fucoidan, also found a similar pattern with that of crude fucoidan from Sargassum sp., but there was a medium peak eluted before the main peak. The similar pattern was also found in the fractionation of Padina sp. crude fucoidan where a major fraction was obtained when the crude fucoidan was eluted with $0.5 \mathrm{M} \mathrm{NaCl}$. This DEAE cellulose column chromatogtaphy showed that a major peak was appeared whith $0.5 \mathrm{M} \mathrm{NaCl}$ elution either for Sargassum sp., Turbinaria sp.or Padina sp. or fucoidan crude extracts. Each major peak was pooled and used for the subsequent experiments.

Pure fucoidans obtained from the DEAE cellulose column chromatography were confirmed by using HPLC (Figure 2) and FTIR spectra (Figure 3). HPLC produced a single peak with the same retention time with standard fucoidan from $F$. vesiculosus. FTIR spectra also confirmed that the obtained compound were fucoidan.The spectra showed the typical bands of polysaccharide. The broad band centered at $3435 \mathrm{~cm}^{-1}$ assigned to hydrogen bonded $\mathrm{O}-\mathrm{H}$ stretching vibration. ${ }^{28-30}$ The band at $2939 \mathrm{~cm}^{-1}$ was attributed the $\mathrm{C}-\mathrm{H}$ stretching pyranoid ring and $\mathrm{C} 6$ of fucose and/or galactose units. ${ }^{13,30}$ The band at $1614 \mathrm{~cm}^{-1}$ indicated the stretching of asymmetric carboxylate O-C-O vibration. ${ }^{28,29}$ The band at $1424 \mathrm{~cm}^{-1}$ suggested $\mathrm{C}-\mathrm{OH}$ deformation vibration with contribution of $\mathrm{O}-\mathrm{C}-\mathrm{O}$ symmetric stretching vibration of carboxylate group..$^{29}$ The presence of $\mathrm{O}=\mathrm{S}=\mathrm{O}$ stretching vibration of sulphate esters was indicated by a band at $1258 \mathrm{~cm}-113,28,29$ The band at $1040 \mathrm{~cm}^{-1}$ corresponded to stretching vibration of $\mathrm{C}-\mathrm{O}-\mathrm{C} / \mathrm{C}-\mathrm{OH} .{ }^{30}$ The band at $820 \mathrm{~cm}^{-1}$ assigned the C-O-S bending vibration of sulfate group..$^{28-31}$ The band at $580 \mathrm{~cm}^{-1}$ indicated the asymmetric and symmetric $\mathrm{O}=\mathrm{S}=\mathrm{O}$ deformation of sulfate. ${ }^{31}$ These FT-IR spectra analysis proved that the extraction and purification processes used and purification process used in this study were effective to obtain fucoidan from the three tropical brown algae.

To evaluate the potential bioactivity of fucoidan as an anti-cancer, a cytotoxicity test against colon cancer cells (human collon adenocarcinoma cells) (WiDr), breast cancer cells (human breast adenocarcinoma cells) (MCF-7) and a normal cells of green monkey kidney cells (Vero cells) was conducted. The cytotoxicity was compared with a standard fucoidan from F. vesiculosus. Results showed that standard fucoidan exhibited high cytotoxic activity against colon cancer and killed almost all cells at a dose of $1000 \mu \mathrm{g} / \mathrm{mL}$ (Figures 4 and 5). Lower cytotoxicity activity was found for three fucoidans from brown algae examined in this study. Fucoidan from Padina sp. showed cytotoxicity comparable with standard fucoidan at concentrations below $100 \mu \mathrm{g} / \mathrm{mL}$. However, increase in the concentrations above $100 \mu \mathrm{g} / \mathrm{mL}$ did not significantly increase in the cytotoxicity activity. The same pattern of cytotoxicity was obtained against breast cancer cells (MCF-7) (Figure 4).

The results of cytotoxicity test also indicated that the cytotoxicity of fucoidan varied depending on the seaweeds species as their sources, and cell lines used. Fucoidan from Sargassum sp. and Turbinaria sp. exhibited low cytotoxic activity with $\mathrm{IC}_{50}$ values in the range of $461-663 \mu \mathrm{g} / \mathrm{mL}$. The cytotoxic activities were lower comparing to the standard fucoidan 

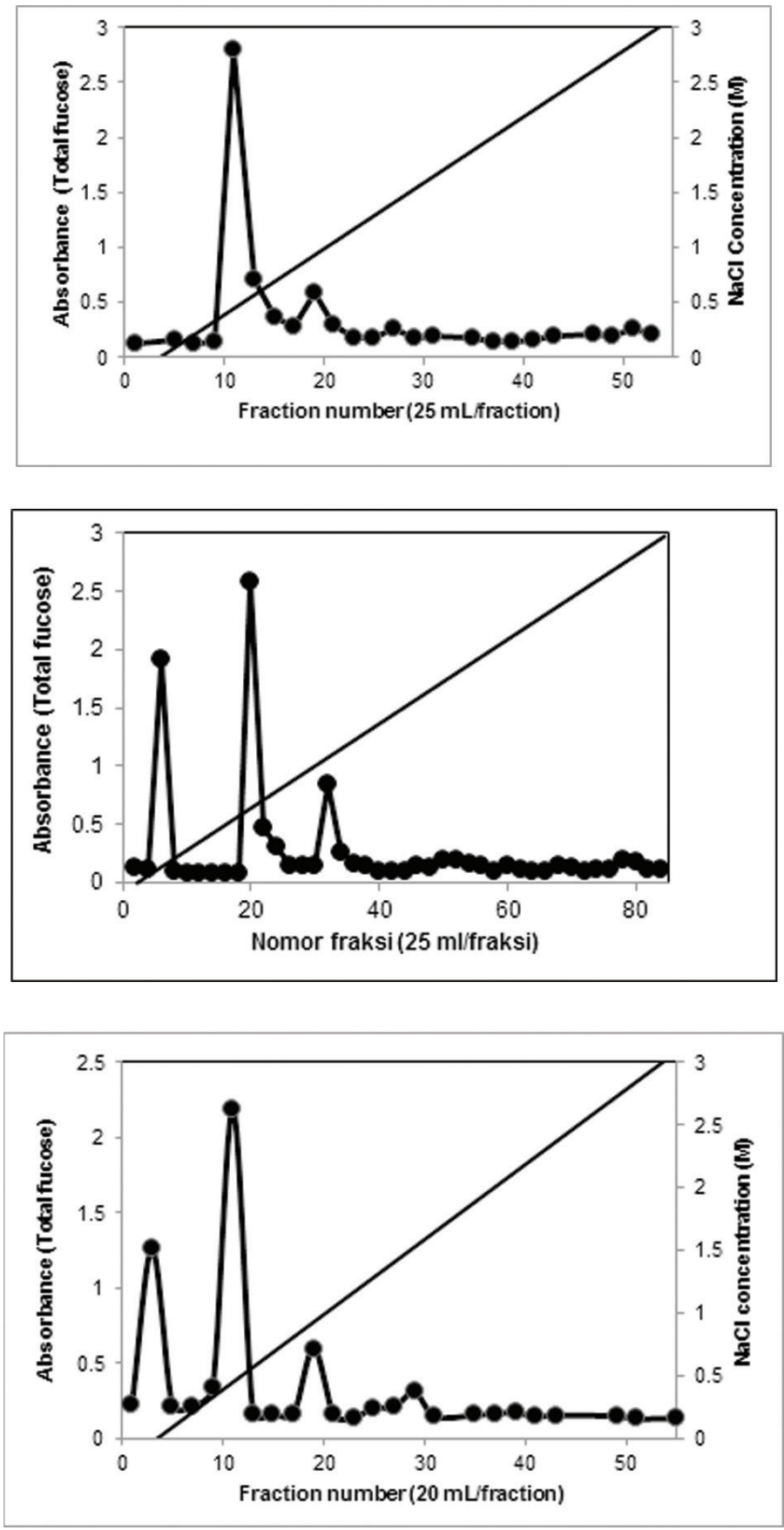

Figure 1: Fractionation of crude fucoidan extracts of Sargassum sp.(A),Turbinaria sp.(B) and Padina sp.(C) based on total sugar content with fucose standard on DEAE cellulose coloumn chromatography.

from F. vesiculosus. Fucoidan from Padina sp. exhibited higher cytotoxic activity with $\mathrm{IC}_{50}$ value of 144 and $118 \mu \mathrm{g} / \mathrm{mL}$ against breast and colon cancer cells, respectively (Table 1). Cytotoxicity of Padina sp. fucoidan was higher than that of standard fucoidan against a normal Vero cells with $\mathrm{IC}_{50} 511 \mu \mathrm{g} / \mathrm{mL}$ and $211 \mu \mathrm{g} / \mathrm{mL}$, respectively, suggested that the former one might be more selective cytotoxic than the later one.

Ale et $a l^{18}$ have evaluated anti-cancer activity of fucoidan from Sargassum sp., against Lewis Lung Carcinoma cells (LLC) and melanoma B16 cells (MC) in low concentration of Fetal Bovine Serum (FBS) (2\%) as used in this study. Results indicated thatSargassum sp. fucoidan reduces the viability of LLC cells up to $40 \pm 7 \%$ at $1,000 \mu \mathrm{g} / \mathrm{mL}$. The cell viability reduction
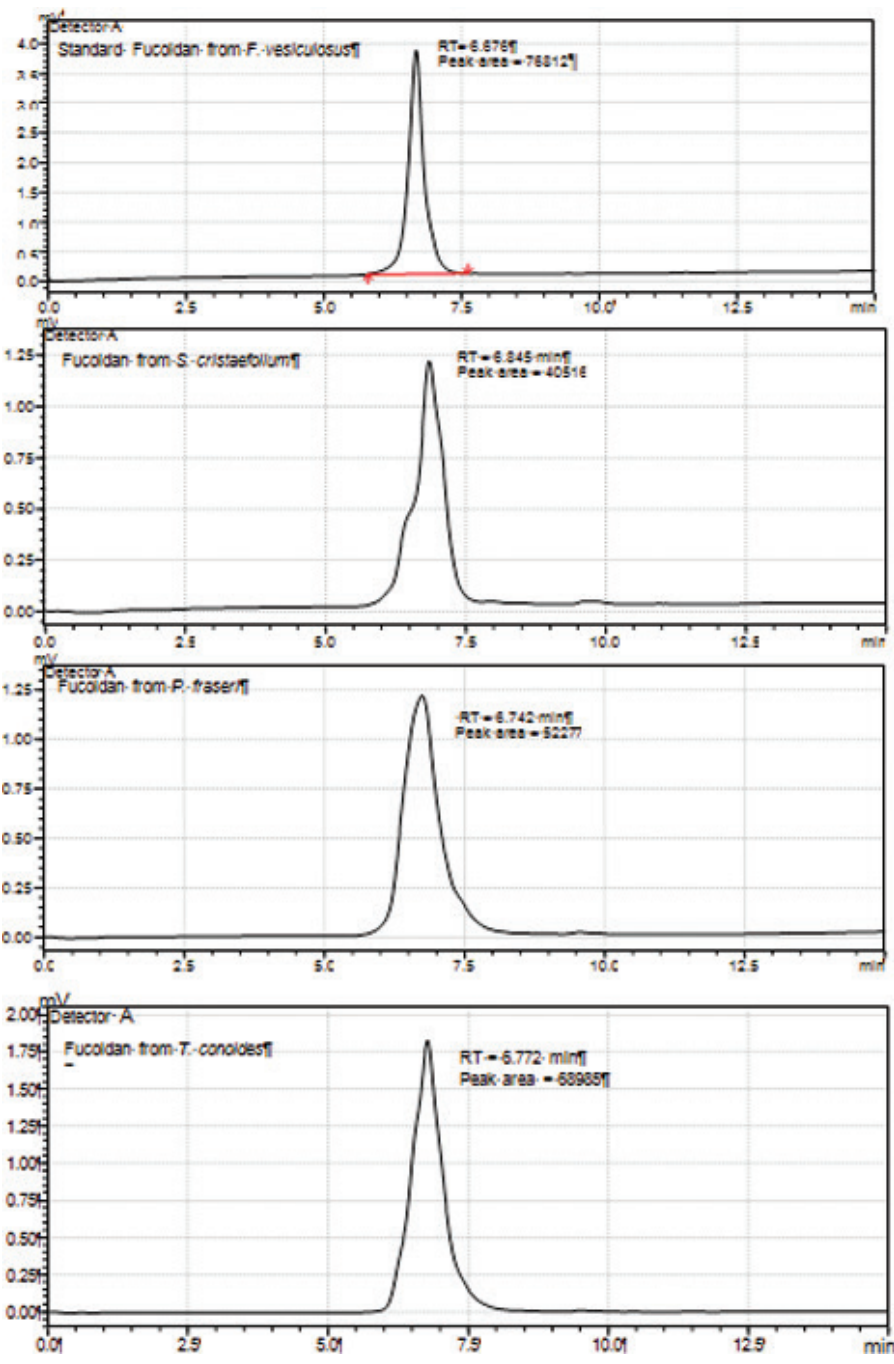

Figure 2: HPLC profile of standard fucoidan and purified fucoidan from Sargassum sp., Turbinaria sp. and Padina sp.

is more signifancantly noted against MC cells, resulting in only $56 \pm 5 \%$ viable cells upon addition of 100 and $200 \mu \mathrm{g} / \mathrm{mL}$. Our study results confirmed that the different fucoidan sources and different cell lines used in cytotoxicity test resulted the variation of cytotoxicity activities. Padina sp. fucoidan used in our study has higher cytotoxicity comparing to that of Sargassum sp. and Turbinaria sp. Without considering the cell lines used in cytotoxicity test, fucoidan from Sargassum sp. against WiDr and MCF-7 exhibited the similar cytotoxicity level with Sargassum sp. used by Ale et al ${ }^{18}$ against LLC cells.

Several studies have evaluated cytotoxicity of fucoidan against collon and breast cancer.,10,16,19 Cumashi et al found that fucoidans from L. saccharina, L. digitata, F. serratus, F. distichus and F. vesiculosus at $100 \mu \mathrm{g} / \mathrm{mL}$ strongly blocked MDAMB-231 breast carcinoma cell adhesion to platelets, an effect which might have critical implications in tumormetastasis. Hyun et $a l^{16}$ reported that fucoidan from $F$. vesiculosus at 100 $\mu \mathrm{g} / \mathrm{mL}$ demonstrates apoptotic activity against HCT-15 cells (human colon carcinoma cells). Fucoidans from S. hornery, Eclonia cava and Costaria costata have been reported non significant cytotoxic activity against human skin melanoma (SK-MEL-28) and colon cancer cells (DLD-1) after treatment during $24 \mathrm{~h}$ at concentration from 1 to 200 $\mu \mathrm{g} / \mathrm{mL} .{ }^{19}$ Fukahori et $a l^{32}$ also have proved by evaluating cytotoxicity of fucoidan against 15 cancer cell lines with the broad range $\mathrm{IC}_{50}$ between 


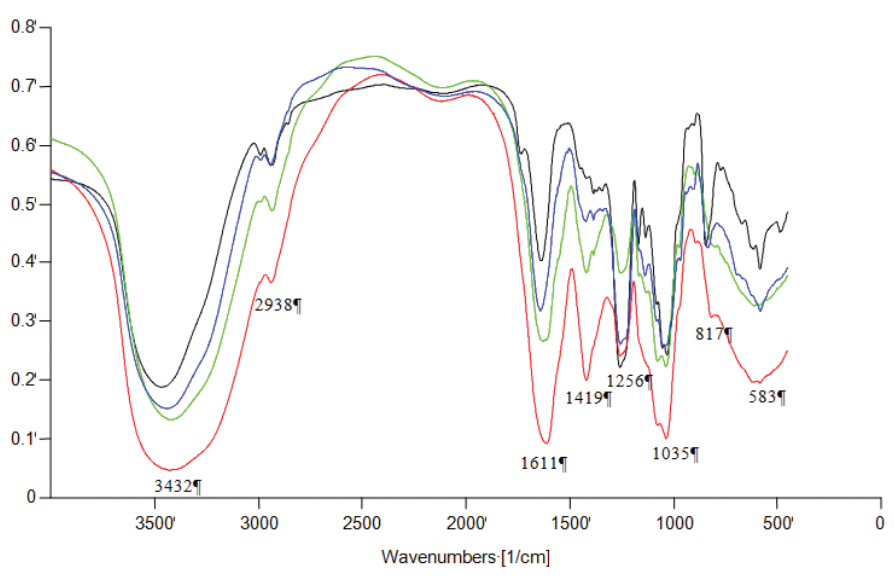

Figure 3: Overlaid FTIR spectra of standard fucoidan (black line) and purified fucoidan from Sargassum sp. (red line), Turbinaria sp.(green line) and Padina sp.(blue line).
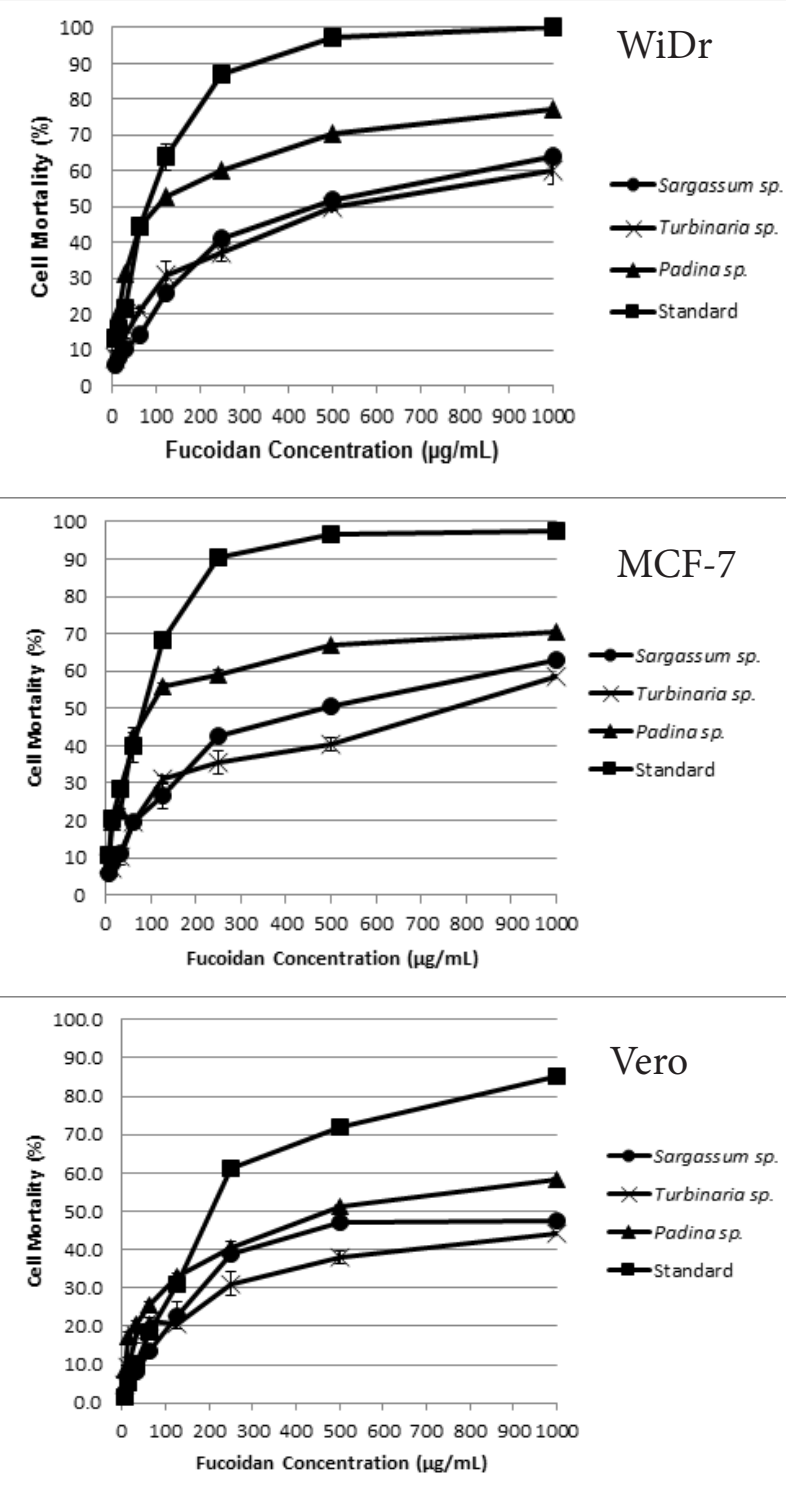

Figure 4: Cytotoxicity of fucoidan from Sargassum sp., Turbinaria sp., Padina sp. and standard fucoidan against human collon adenocarcinoma (WiDr) human breast adenocarcinoma (MCF-7) and kidney green monkey (Vero) cells.
Tabel 1: IC $C_{50}$ of fucoidan from Sargassum sp., Turbinaria sp., Padina sp. and fucoidan standard against human breast adenocarcinoma (MCF-7), human collon adenocarcinoma (WiDr) and kindey epithelial African green monkey (Vero) cells

\begin{tabular}{cccc}
\hline \multirow{2}{*}{ Fucoidan Sample } & \multicolumn{3}{c}{$\mathrm{IC}_{50}(\mu \mathrm{g} / \mathrm{mL})$} \\
\cline { 2 - 4 } & MCF-7 & WiDr & Vero \\
\hline Sargassum sp. & 461 & 476 & 757 \\
Turbinaria sp. & 663 & 547 & $>1000$ \\
Padina sp. & 144 & 118 & 501 \\
Standard Fucoidan & 60 & 63 & 211 \\
\hline
\end{tabular}

18.71and $299.20 \mu \mathrm{g} / \mathrm{mL}$. The above reports indicate that the cytotoxicities of fucoidan are greatly vary depending on the sources of fucoidan and cell lines used in cytotoxicity assay. Results of our study confirmed fucoidans from three tropical brown seaweeds exhibits cytotoxicity variation. Fucoidan from Padina sp. shows selective cytotoxicity with $\mathrm{IC}_{50} 118$ to $144 \mu \mathrm{g} / \mathrm{mL}$ against cancer cell lines and $501 \mu \mathrm{g} / \mathrm{mL}$ against a normal cell line suggested that this brown seaweed may a prospective source of fucoidan for developing cytotoxic agent in cancer therapy especially against breast and collon cancer. The further studies are needed to investigate the variability of fucoidan related to the season, sampling location and extraction method, and also evaluation of the cytotoxicity against more broad range cancer cell lines.

\section{ACKNOWLEDGEMENTS}

This research was financially supported by a grant from Directorate of Higher Education, Ministry of Education and Culture, the Republic of Indonesia under the program of Hibah Kompetensi (Competency Research Grant) 2013/2014.

\section{CONFLICT OF INTEREST}

We do not have any conflict of interest.

\section{REFERENCES}

1. Chizhov AO, Dell A, Morris HR, Haslam SM, McDowell RA, Shashkov AS, et al. A study of fucoidan from the brown seaweed Chorda filum. Carbohydr Res. 1999;320(1):108-19. http://dx.doi.org/10.1016/S0008-6215(99)00148-2.

2. Pereira MS, Mulloy B, Mourão PA. Structure and anticoagulant activityof sulfated fucans. Comparison between the regular, repetitive, and linearfucans from echinoderms with the more heterogeneous and branched polymersfrom brown algae. J Biol Chem. 1999;274(12):765-67. http://dx.doi.org/10.1074/ jbc.274.12.7656.

3. Li B, Lu F, Wei X, Zhao R. Fucoidan: structure and bioactivity. Molecules. 2008;13:1671-95. http://dx.doi.org/10.3390/molecules13081671.

4. Synytsya A, KimW-J, Kim S-M, PohIR, Synytsya A, Kvasnicka F, Copikova J, ParkYI. Structure and antitumour activity of fucoidan isolated from sporophyll of Korean brown seaweed Undaria pinnatifida. Carbohydr Polym. 2010:81(1):41-8. http:// dx.doi.org/10.1016/j.carbpol.2010.01.052.

5. Cumashi A, Ushakova NA, Preobrazhenskaya ME, D'InceccoA, PiccoliA, Totani L, et al. A comparative study of the anti-inflammatory, anticoagulant, antiangiogenic, andanti adhesive activities of nine different fucoidans from brown seaweeds. Glycobiology. 2007;17(5):541-52. http://dx.doi.org/10.1093/glycob/ cwm014.

6. Yoo Y-C, Kim W-J, Kim S-Y, Kim S-M, Park Y-I. Immunomodulating activity of a fucoidan isolated from Korean Undaria pinnatifid as porophyll. Algae. 2007;22(4):333-8. http://dx.doi.org/10.4490/ALGAE.2007.22.4.333.

7. Teruya T, Takeda S, Tamaki Y, Tako M. Fucoidan isolated from Laminaria angustata var longissima induced macrophage activation. Biosci Biotechnol Biochem. 2010;74(9):1960-2. http://dx.doi.org/10.1271/bbb.100294.

8. Ramberg JE, Nelson ED, Sinnott RA. Immunomodulatory dietary polysaccharides: a systematic review of the literature. Nutrition J. 2010;9(1):54. http:// www.nutritionj.com/content/9/1/54. http://dx.doi.org/10.1186/1475-2891-9-54.

9. Isnansetyo A, Fikriyah A, Kasanah N, Murwantoko. Non specific immune potentiating activity of fucoidan from a tropical brown algae (Phaeophyceae), 

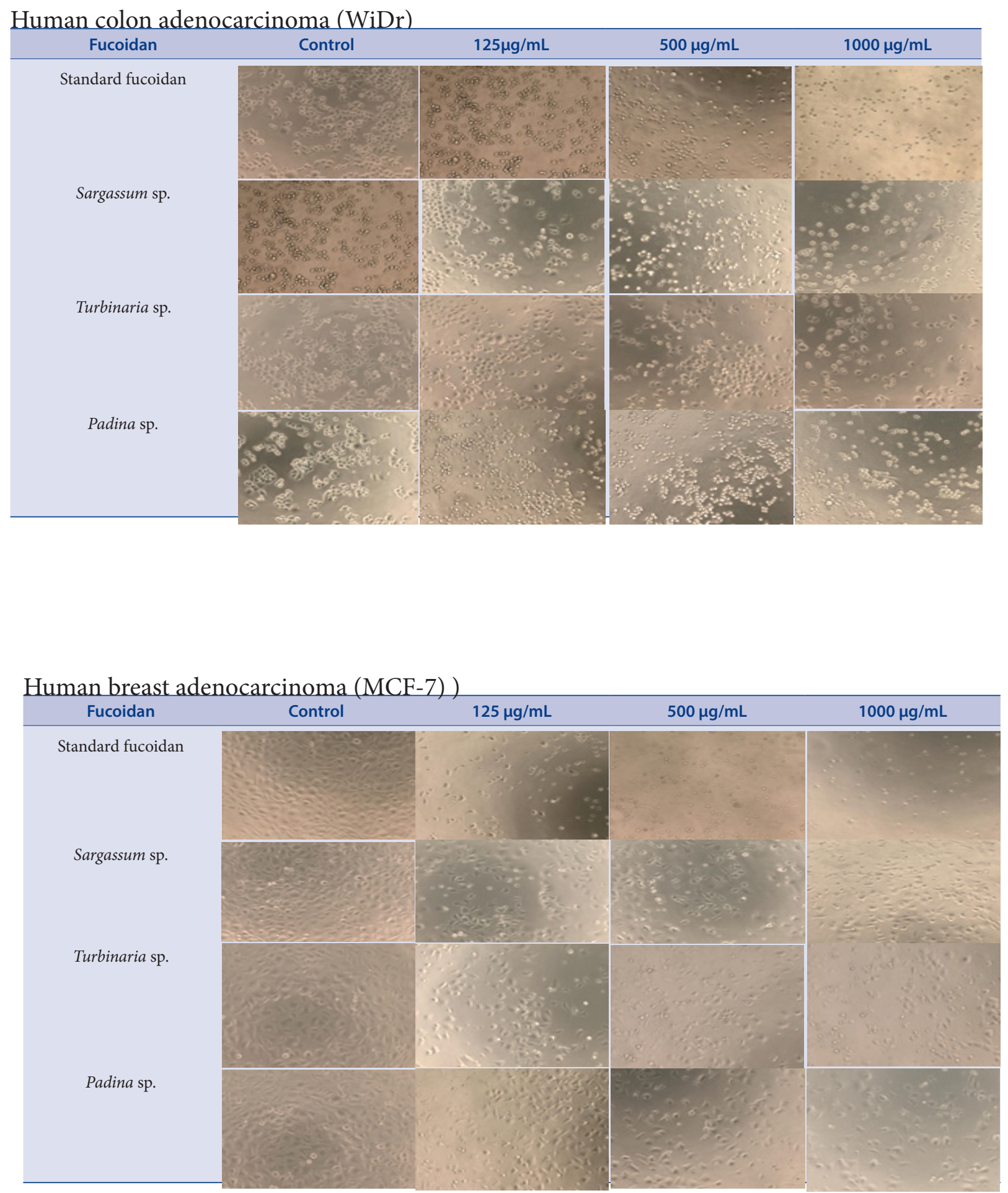


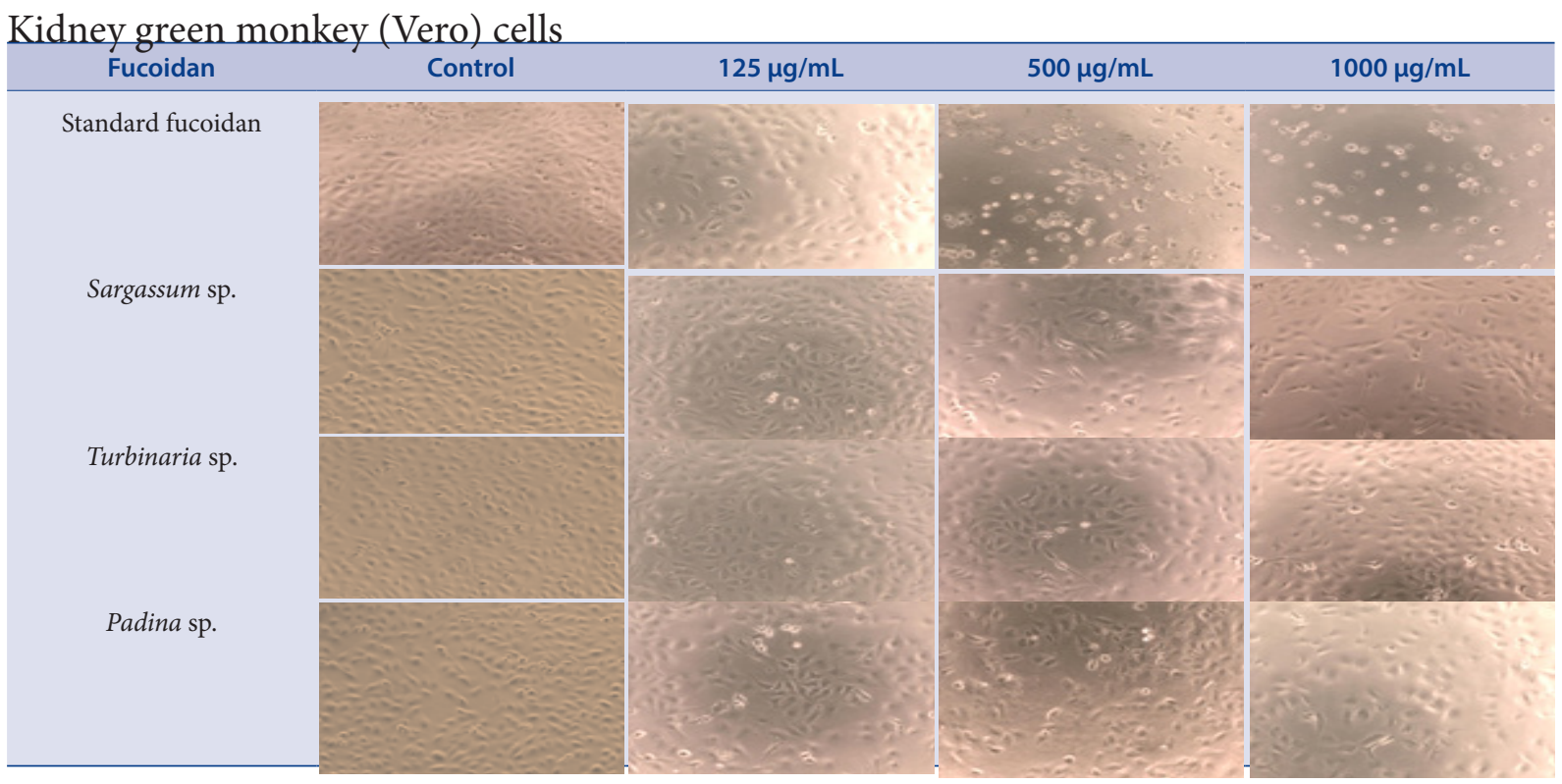

Figure 5: Morphology and density changes of human collon adenocarcinoma (WiDr) human breast adenocarcinoma (MCF-7) and kidney green monkey (Vero) cells treated with standard fucoidan and fucoidan from Sargassum sp., Turbinaria sp., Padina sp. at various concentrations

Sargassum cristaefolium in tilapia (Oreochromis niloticus). Aquacult. Int In Press. 2016;24(2):465-477. http://dx.doi.org/10.1007/s10499-015-9938-z.

10. Kawamoto H, Miki Y, Kimura T, Tanaka K, Nakagawa T. Effects of fucoidan from mozuku on human stomach cell lines. Food SciTechnol Res. 2006;12(3):218-22. http://dx.doi.org/10.3136/fstr.12.218.

11. Kim EJ, Park SY, Lee J-Y, ParkJHY. Fucoidan present in brown algae induces apoptosis of human colon cancer cells. BMC Gastroenterol. 2010;10(1):96. http:// www.biomedcentral.com/1471-230X/10/96. http://dx.doi.org/10.1186/1471230X-10-96

12. World Health Organization.org. Geneva: World Health Organization. [updated 2015, February; cited 2015 November 29]. Available from http://www.who.int/ mediacentre/factsheets/fs297/en/index.html.

13. World Health Organization.org. Geneva: World Health Organization. (updated 2013, January; cited 2015 November 29). Available from http://www.who.int/ features/factfiles/cancer/en/.

14. Girish HV, Vinod AB, Dhananjaya BL, Kumar SD, Duraisamy S. The anticance potential of pavonia odorata willd. extract on human breast (MD-MB-231), prostate (PC-3) and lung (Calu-6) cancer cell lines. Pharmacogn J. 2016;8(1):28-30

15. Syam S, Bustamam A, Abdullah R, Sukari MA, Hashim NM, Yahayu M, et al. Cytotoxicity and oral acute toxicity studies of b-mangostin isolated from Cratoxylum arborescens. Pharmacogn J. 2014;6(1):47-56. http://dx.doi.org/10.5530/ pj.2014.1.8.

16. Hyun JH, Kim SC, Kang JL, Kim MK, Boo HJ, Kwon JM, et al. Apoptosis inducing activity of fucoidan in HCT-15 colon carcinomacells. Biol Pharm Bull. 2009;32(10):1760-4. http://dx.doi.org/10.1248/bpb.32.1760.

17. Senthilkumar K, Manivasagan P, Venkatesan J, Kim S-K. Brown seaweed fucoidan: Biological activity and apoptosis, growth signaling mechanism in cancer. Int J Biol Macromol. 2013;60:366-74. http://dx.doi.org/10.1016/j. ijbiomac.2013.06.030.

18. Ale MT, Maruyama H, Tamauchi $H$, Mikkelsen JD, Meyer AS. Fucoidan from Sargassum sp. and Fucus vesiculosus reduces cell viability of lungcarcinoma and melanoma cells in vitro and activates natural killer cells in mice in vivo. Int J Biol Macromol. 2011;49(3):331-6. http://dx.doi.org/10.1016/j.ijbiomac.2011.05.009.

19. Ermakova S, Sokolova R, Kim SM, Um BH, Isakov V, Zvyagintseva T. Fucoidans from brown seaweeds Sargassum hornery, Eclonia cava, Costaria costata: structural characteristics and anticancer activity. Appl Biochem Biotechnol. 2011;164(6):841-50. http://dx.doi.org/10.1007/s12010-011-9178-2

20. Murphy C, Hotchkiss S, Worthington J, McKeown SR. The potential of seaweed as a source of drugsfor use in cancer chemotherapy. J App Phycol. 2014;26(5):2211-64. http://dx.doi.org/10.1007/s10811-014-0245-2.
21. Marudhupandi T, Kumar TTA, senthil SL, Suja G, Vinothkumar T. In vitro anticancer activity of fucoidan from Turbinaria conoides against A549 cell lines. Int J Biol Macromol. 2015;72:919-23. http://dx.doi.org/10.1016/j.jibiomac.2014.10.005.

22. Dhargalkar VK, Kavlekar D. Seaweeds: a field manual. 2004; National Institute of Oceanography, Dona Paula.36 p.

23. Trono Jr GC.Seaweeds In: FAO Species Identification Guide For Fishery PurposesThe Living Marine Resources of The Western Central Pacific Vol. 1 Seaweeds, corals, bivalves and gastropods. Carpenterand KE, NiemVH (Eds.) 1998;FAO.Rome. 1-100.

24. Rioux D, Colliec-Jouault S, Pinczon D, Bosch S, Siavoshian S, LeBert V, et al. Antitumor and antiproliferative effects of a fucan extracted from Ascophyllum nodosum against a non-small-cell bronchopulmonary carcinoma line. Anticancer Res. 1996;16(13):1213-8.

25. Masuko T, Minami A, Iwasaki N, Majima T, Nishimura SI, Lee YC. Carbohydrateanalysis by a phenol-sulfuric acid method in microplate format. Anal Biochem. 2005;339(1):69-72. http://dx.doi.org/10.1016/j.ab.2004.12.001.

26. Dodgson KS, Price RG. A note on the determination of the ester sulphate content of sulphated polysaccharides. Biochem 1962;84(1):106-10. J. http://dx.doi.org/ 10.1042/bj0840106.

27. Isnansetyo A, Kamei Y. MC21-A, a bactericidal antibiotic produced by a new marine bacterium, Pseudoalteromonas phenolica sp. nov., against methicillinresistant Staphylococcus aureus (MRSA). Antimicrob Agents Chemother 2003;47(2):480-8. http://dx.doi.org/10.1128/AAC.47.2.480-488.2003

28. Silva TMA, Alves LG, de Queiroz KCS, Santos MGL, Marques CT, Leite EL. Partial characterization and anticoagulant activity of a heterofucan from the brown seaweed Padina gymnospora. Braz J Med Biol Res. 2005;38(4):523-33. http://dx.doi.org/10.1590/S0100-879X2005000400005

29. Immanuel G, velmurugan MS, Marudhupandi T, Radhakrishnan S, Palavesam A The effect of fucoidan from brown seaweed Sargassum wightii on WSSV resistance and immune activity in shrimp Penaeus monodon (Fab). Fish \& Shellfish Immunol. 2012;32(4):551-64. http://dx.doi.org/10.1016/j.fsi.2012.01.003.

30. Wang $Q$, Song $Y, H e Y$, Ren D, Kow F, Qiao Z, et al. Structural characterisation of algae Costaria costata fucoidan and its effects on $\mathrm{CCl} 4$-induced liver injury. Carbohydr Polym. 2014;107:247-54. http://dx.doi.org/10.1016/j.carbpol.2014.02.071.

31. Pielesz A, Binias W. Cellulose acetate membrane electrophoresis and FTIR spectroscopy as methods of identifying a fucoidan in Fucus vesiculosus Linnaeus, Carbohydr Res. 2010;345(18):2676-82. http://dx.doi.org/10.1016/j. carres.2010.09.027. 
32. Fukahori S, Yano H, Akiba J, Ogasawara S, Momosaki S, Kojiro M. Fucoidan. A major component of brown seaweed prohibits the growth of human cancer

Cite this article : Isnansetyo A, Laili Lutfia FN, Nursid M, Trijoko, Susidarti RA. Cytotoxicity of Fucoidan from Three Tropical Brown Algae Against Breast and Colon Cancer Cell Lines. Pharmacog J. 2017;9(1):14-20. cell lines in vitro. Mol Med Rep. 2008;1(4):537-54. http://dx.doi.org/10.3892/ mmr.1.4.537. 